\title{
The Political Law of Presidential Regulation on the Handling of Refugees in Indonesia
}

\author{
Liza Shahnaz \\ M.HSC., M.H., lecturer, Faculty of Law, Borneo Tarakan University, Tarakan, Indonesia \\ Dewi Nurvianti \\ M.H., lecturer, Faculty of Law, Borneo Tarakan University, Tarakan, Indonesia \\ Yahya Ahmad Zein \\ DR, lecturer, Faculty of Law, Borneo Tarakan University, Tarakan, Indonesia
}

\begin{abstract}
Indonesia has been dealing with refugees since 1950s, despite the fact that the country has never been a party to the 1951 Refugees Convention and its 1967 Protocol. As of May 2017, according to UNHCR (United Nations High Commissioner for Refugees), Indonesia has been hosting 14,500 refugees from more than 57 countries. In handling of refugees, Indonesia puts forward the value of human rights that in line with its nation's ideology (Pancasila) and its constitutions (UUD 1945), and Regulation Number 39 Year 1999 pertaining to human rights. At the end of 2016, president of Indonesia releases new regulation pertaining this matter to show its willingness and strong commitment to help these refugees. Therefore, this new regulation is expected to balance out the challenge as well as the threat that might harm the nation with the arrival of these foreigners and the implementation of existing regulations on human rights. Thus, this research examines about the ius constitutum and ius constituendum pertaining to the handling of refugees in Indonesia. This research is legal research, using statute approach and descriptive legal research. Ultimately, the results of this research are expected to give more insights on the handling of refugees in a non-state party to the other state parties to the 1951 convention relating to the status of refugee.
\end{abstract}

Keywords: refugees, human rights, presidential regulation, Indonesia

\section{Background of Study}

The world is now witnessing human movement at its the highest level due to the advancement of technology and types of transportation. People may cross cities, countries, and even continents within days or hours. International law, actually, recognizes the freedom of human movement in two major instruments, namely the Universal Human Declaration of Human Rights and International Covenant on Civil and Political Rights. In the Article 13 of Universal Declaration of Human Rights, it stated that:

(1) Everyone has the right to freedom of movement and residence within the borders of each state;

(2) Everyone has the right to leave any countries, including his/her own, and return to his/her country.

In addition, the Article 12 of the International Covenant on Civil and Political Rights stated that:

(1) Everyone lawfully within the territory of a state shall, within that territory, has the right to liberty of movement and freedom to choose his/her residence.

(2) Everyone shall be free to leave any country, including his/her own. 
(3) The above-mentioned rights shall not be subject to any restrictions except those which are provided by law, are necessary to protect national security, public order, public health, or morals, or the rights to freedom of others and are consistent with the other rights recognized in the present Covenant.

(4) No one shall arbitrarily deprive of the right to enter his/her own country.

Despite these existing rules in international law, every country has the rights to set up its own rules and regulations pertaining to people entering and leaving their sovereign territory, including Indonesia as one of the sovereign states. Indonesia has immigration rules under Law Number 6 Year 2011, which explains immigration is a matter of traffic of people entering and leaving the sovereign territory of the Republic of Indonesia and its supervision to maintain the sovereign of the state ${ }^{1}$. This law has consequences for every foreigner to have certain permit to get into the territory of Indonesia. Moreover, Sigit Riyanto added the domestic law on immigration only applicable for common immigration problems (Charliene, 2017), not for those refugees who have to leave their country for the sake of their life. However, the 1945 Indonesia Constitution stated in Article 28G that:

(1) Every person shall have the right to protection of his/herself, family, honour, dignity, and property, and shall have the right to feel secure against and receive protection from the threat of fear to do or not do something that is a human right;

(2) Every person shall have the right to be free from torture or inhumane and degrading treatment, and shall have the right to obtain political asylum from another country.

Hence, many occurrences of regulations imply Indonesia stance on refugees and asylum seekers, such as Law Number 37 Year 1999 on International Relations and Law Number 39 Year 1999 on Human Rights. These legal instruments imply the protection on refugee and asylum seeker entering Indonesia territory based on human rights.

Indonesia is a non-contracting state to the 1951 Convention Relating to the Status of Refugee, which means Indonesia is not legally bound to provide protection for refugees. But the current record on people displacement reaches the highest level in the history, where every day over 28, 000 people are forced to leave their homes due to internal conflict and persecution (UNHCR, 2018). These people almost have no access to basic rights, such as education, healthcare, employment, and freedom of movement and until the end of 2017, around 13,840 refugees and asylum seekers are registered at UNHCR (United Nations High Commissioner for Refugees) Indonesia and comes from Afghanistan (55\%), Somalia (11\%), and Iraq (6\%) (UNHCR di Indonesia, 2018). Finally, President Joko Widodo released Presidential Regulation Number 125 Year 2016 pertaining the handling of refugees. This presidential regulation actually has been drafted since 2013 and contains the mechanism of protection to refugee and asylum seeker.

With all the current regulations provided from Indonesia (ius constitutum), it is also necessary to look at on how those regulations should be ideally practice (ius constituendum). Therefore, the main discussion of this study will focus on the ius constitutum and ius constituendum of the handling of refugees in Indonesia.

\section{Literature Review}

This part discusses two main concepts in this study; they are political law and refugees.

1 Article 1 Paragraph 1. 


\section{Political Law}

Political law encompasses the study of the activities of a broader array of legal actors, such as legislators and regulators, non-profit organization advocates, and practitioners working for law firms, political parties, corporations, trade associations, and unions. Political law also covers non-election topics, such as lobbying, pay-to-play, and gift regulations (Cain, 1999).

Satjipto Rahardjo defines the political law is an activity of choosing and a path to be used to achieve a certain social and legal purpose in society (Rahardjo, 2000). Meanwhile, Padmo Wahjono defines the political law is basic policy that determines the direction, form, and content of law to be formed (Wahjono, 1986). This definition is still abstract and then comes with an article entitled "menelisik peraturan perundang-undangan", which says that the political law is the policy of state organizers about what is used as criteria to punish something. In this case, that policy related to the formation, application, and enforcement of law (Wahyono, 1991). Furthermore, according to Soedarto, political law is the state policy through state bodies that has authority to establish desired rules that expected be used to express what is contained in society and to achieve what is aspired to (Soedarto, 1983).

The legal politics of each country is different. This is due to differences in historical background, world-view, socio-cultural, and political will of them. In other words, political law is local and particular, so that it is valid only from and for the country itself, not universal. However, it is not a reason for a country to ignore reality and politics of international law.

William Zevenberg (2011) points out that political law is trying to answer on which the appropriate regulations become a law (p. 19). That regulation is a form of political law, including the process of making and implementing the law, which can indicate type and direction to which the law will be built. Political law provides a basis for more legal process of suitable formation, situation and conditions, culture and values that develop in society, regarding to necessary of society. Political law is divided into two dimensions. First, political law is basic reason to regulate the rule. Second, it becomes the reason of legislation enforcement.

Based on all the definition of political law above, generally, political law is a policy that has been taken by the state through the bodies or official authorized to determine which law need to be retained, to be regulated or to be issued, so that the state's goals can be gradually achieved (Hamidi, 2009, pp. 232-241).

\section{Refugees}

Determination of refugee status, in practice, is administered by UNHCR in the states which are not party to the 1951 Refugee Convention or in the states who are already party to the 1951 Refugee Convention but they have no mechanism or procedure for determining an asylum (Clarissa, 2014, p. 23). Most forced migrants are unable to move directly to a place of permanent resettlement due to the unplanned and unanticipated nature of the move. Hence, the role of transit country in international migrations increases because this process can go on for a while and pass through certain locations, before they can reach their final destination.

Basically, protection for asylum seeker and refugee is the responsibility of every state whether it ratifies the 1951 Convention Relating to the Status of Refugee and its 1967 Protocol or not. The thing that differentiates between state party and non-state party is the coverage of the rights and obligations between the two. Obviously, state party has broader rights and obligations than non-state party. To the date, Indonesia views asylum seeker as illegal migrant due to the fact that most of them enter Indonesia territory unlawfully by breaching Indonesia's immigration law with the absence of valid immigration document. This situation leads to 
arrest and they end up in a detention center.

According to current Indonesian law, refugee and asylum seeker who enter Indonesia's territory illegally is categorized as illegal migrant. It means that Indonesia has no mechanism which deals specifically with refugee and asylum seeker. The UNHCR (the United Nations Refugee Agency), has an office in Indonesia that is responsible for registering asylum seekers and conducting Refugee Status Determination (RSD) on behalf of the Government of Indonesia.

Related to the condition where Indonesia is not a party of refugee convention, UNHCR suggests recommendations for Indonesian Government, and they are (Human Rights Watch, 2013, p. 91):

1. To immediately review all immigration detention policies, to end guards' physical abuse of detainees, and to improve the appalling conditions of detention.

2. To immediately release all unaccompanied migrant children, and to actively explore alternatives to detention for children.

3. To ensure that, in the rare occasions where children are detained, that conditions are suitable, that children are not held with unrelated adults, and that they have access to education.

4. To ensure that unaccompanied migrant children are granted guardians, legal assistance, and assistance with their basic needs.

5. To ratify the 1951 Convention Relating to the Status of Refugee and to implement a fair, humane, and speedy asylum system.

6. To take wide-reaching measures in responding to the needs of asylum seekers and refugees throughout the asylum process, including providing wide-ranging options for life in Indonesia.

\section{Research Methodology}

Legal research is a scientific activity based on certain methods, systematics, and thoughts; it also aims to analyze a particular legal phenomenon (Soekanto, 1981). A deep analysis is conducted on a legal factor to seek a solution to problems that may occur.

\section{Research Type}

There are two types of legal research, that is, socio-legal research and normative legal research. Socio-legal research considers law as a social phenomenon with a structural approach (Wignyosoebrata, 1993). This type of research is relevant to assess the relationship between law and society in order to find out the implementation of law in the society; hence it is frequently referred to as "law in action". On the other hand, a normative legal research is also known as a doctrinal method (Amiruddin, 2004, p. 118), or a study of documents that uses secondary data as the sources, such as existing regulations, court decisions, and doctrines (Santoso, 2005). A normative legal research is appropriate tool to evaluate legal doctrines, theories, principles, or substances of positive legal orders; therefore it is commonly referred to as "law in books" (Shahrullah \& Syarif, 2015, p. 311). This study adopts a normative legal approach to evaluate the scope and material provisions in Presidential Regulation Number 125 of 2016. In addition, this research also adopts descriptive analysis, which aims to obtain description about juridical symptoms that occur in society.

\section{Data}

Based on the problem statements, this study uses the library data, while the data source is secondary data obtaining through various reading materials related to the problem. 


\section{Findings}

Every country has unique legal political feature. It is due to differences in historical background, socio-cultural and political will of each government. Nevertheless, the political realities also give an impact for the feature. Including Indonesia, which embraces a political of national law, the scope of its application is limited solely for Indonesian territory.

Any foreigner who wishes to enter and to settle in Indonesia should be considered in both ways, economic and socio-cultural aspects. From the economic aspects, the foreigners are considered has the ability to support himself, mainly financially, while staying in Indonesia. From the socio-cultural aspect, the foreigners are also expected to give the highest respect to local culture, such as in their way of dressing while in Indonesia. This principle is normal in the sense that every foreigner entering the territory of Indonesia should be able to provide positive impacts to Indonesian, especially when linked to its national development, scientific and technological progress, and regional as well as global cooperation development.

The politics of Indonesian law is a policy that has been established by Indonesian founding fathers since before its independence. National legal politics was first formally created by the founding fathers, namely Pancasila as a "mirror" of cultural diversity and customs of the nation in the unitary state of the Republic of Indonesia (NKRI). Pancasila is main principle that becomes guideline and ground norms in formulating the 1945 Constitution and other Indonesian regulations. Pancasila is the nation's philosophy, ideology, and the highest source of norms, which is essentially that every provision should be in line with it, hence, Pancasila is considered as legal ideal (rechtsidee) for Indonesian (Hamid At-Tamimi, 1993). ${ }^{2}$

National legal politics is a tool and means used by governments to establish national legal systems, as explained by Mahfud MD that legal politics is a legal policy for law enforcement to achieve the state goals (Mahfud MD, 1998). This national legal system will be able to achieve the ideals of nation as listed in the state ideology foundation, Pancasila, and also listed in the preamble of the 1945 Constitution.

From the definition of political law, it explains that political law is a study not only talking about the existing regulations in a state (ius constitutum), but also discussing about process of the laws that is being and will be enforced (ius constituendum). Furthermore, ius constitutum and ius constituendum in handling refugees in Indonesia are the main discussion in this article.

\section{Ius Constitutum in Handling Refugees in Indonesia}

Indonesia, like many other countries in the Asia Pacific and other part of the world, is visited by forced migrants who escape from prolonged conflict in their home country, seeking asylum and new residence in other country. This international-forced migration phenomenon prompted the United Nations to establish the UNHCR (United Nations High Commissioner for Refugees) in 1950, which a year later regulated the 1951 Convention on Relating to the Status of Refugees and in 1967 followed by its Protocol. Up to today, Indonesia has not been ratified the 1951 Refugees Convention, so normatively the asylum seekers are only allowed to stay temporarily, while seeking the status of refugees by UNHCR to be resettled in refugee-receiving countries

\footnotetext{
${ }^{2}$ The ideals of customary law, the ideals of Islamic law, and the ideals of ex western law apply in Indonesia before Indonesia became independent. However, after the independence of Indonesia, the three ideals of the law will become the raw material in the formation of national legal ideals in Indonesia, commonly called the ideals of Pancasila law. Zainuddin Ali assumes the normative juridical.
} 
("third countries", i.e., the state party of the convention and its protocol). ${ }^{3}$

The arrival sporadically of asylum seekers from various countries creates problems to a country, including Indonesia. Apparently, controlling the foreigner movement in a vast area like Indonesia is not easy. The entry of foreigners to Indonesia with various reasons, some of them come to Indonesia to escape from the fear or to escape from conflict in their home country, by the 1951 Convention those people categorized as refugees.

In any case, position of Indonesia that lies between two oceans and two continents, makes Indonesia as a strategic country as well as a country of transit for the refugees, mostly from Asian to Australian continent. In fact, since 1999, Indonesia has become a transit point especially for the movement of Middle Eastern people who mostly headed to Christmas Island of Australia. At the end, Indonesian government has difficulty in handling refugees, although according to the Indonesian law there is no interest on whatsoever in relation to the refugees. From international law aspect, Indonesia is not a state-party of the 1951 Convention on Relating to the Status of Refugee and the 1967 Protocol, so the country does not have the obligation to provide Refugee Status Determination (RSD). So that a regulation of issues concerning refugees is established by UNHCR according to the mandate it receives under the 1950 Statute of UNHCR (Krustiyati, 2012, p. 174).

Although refugee handling is fully mandated by UNHCR and the Indonesian government has no authority over refugee issues, at least Indonesia has a fixed mechanism in dealing with refugees who are arriving in Indonesia. That mechanism can be achieved in legislation or other legal instruments, so that the stability of Indonesian security can go well without any problems with refugees.

Historically, Indonesia has long experience in dealing with refugee problem since 1979 to present days. There is no comprehensive legal instrument to deal with refugee problem, such as the issue of claims of foreigners seeking asylum to gain recognition of refugee status, while truthfully, Indonesia is a transit country only. However, Indonesia views and addresses this issue as a universal human rights issue, which is that the human rights aspect has been set in the ideology of Indonesian nation, particularly in the second principle of Pancasila that is "just and civilized humanity". The provision on human rights also regulated by the 1945 Indonesian Constitution especially on Article 28A to 28J.

Moreover, in relation to the implementation of human rights treatment based on Pancasila and the 1945 Constitution as described above, Indonesia also has a set of legal instruments related to human rights in the regulations under the 1945 Constitution, such as:

1. Decree of MPR. No. XVII/MPR/1998, which contains the Human Rights Charter;

2. The amendment of the 1945 Constitution; Article 28G of Paragraph 2 stipulates that everyone has the right to be free from torture or degrading treatment of human dignity and entitled to obtain political asylum from other countries;

3. Law No. 39 of 1999; Article 28 Paragraph 1 states that everyone is entitled to seek asylum to obtain political protection from other countries; Paragraph 2 affirms that right shall not apply to those, who commit non-political crimes or acts contrary to the purposes of the UN principle;

4. Law No. 37 of 1999 on Foreign Relations; Article 25 Paragraph 1 states that the President has authority to grant asylum to a foreigner; Paragraph 2 provides that authority is exercised through a Presidential Decree. Article 26 provides for the granting of asylum to foreigner carried out according to with national legislation and

\footnotetext{
3 These countries, for example in the EU, harmonized the policies on refugees with national legislation to manage asylum seekers and refugees, to resettle and to integrate refugees in their territories, although this policy is increasingly unpopular there.
} 
by observing international law, custom, and practice;

5. Ratification of Convention Against Torture and Other Cruel, in Human or Degrading Treatment or Punishment with Law No. 5 of 1998, in Article 3 of this Convention states that states parties are prohibited from taking non-refoulement measures, repatriation, or extradition of a person to another country. Then, any asylum seekers must be accepted by the country where the individual is applying for asylum;

6. Law No. 1 of 1979 on Extradition, in Article 5 Paragraph 1 stated that extradition is not made against political crimes. Subsequently in Article 14 affirmed that the extradition request is denied, if there are reasonable allegations that the extradition requested shall be prosecuted, in connection with his/her religion, political or civic belief or because he/she belongs to a particular ethnic group or population. The same reasons are with the basic protection and determination of refugee status according to Article 1 of the 1951 Convention.

Currently, with the existing rules in Indonesia although Indonesia is not a party to the 1951 Convention, the management of refugees in Indonesia is highly appreciated by UNHCR (Indonesia-UPR Info., 2018). However, Indonesia should not be complacent, because the presence of foreigners in a country will create new problems, such as threats to internal security.

In response to the situation, the Indonesian Government on December 31st, 2016 issued Presidential Regulation Number 125 Year 2016. This regulation is expected to aspire for Indonesian, where the regulation on refugees' management not only regulates humanitarian aspect given to the refugees but gives a sense of security for Indonesia and its people.

\section{Ius Constituendum in Handling Refugees in Indonesia}

International Refugee Law as a new branch within the discipline of international law is very urgent, especially for Indonesia as a transit country for refugees and asylum seekers. Therefore, Indonesia needs special arrangements relating to the protecting and handling of refugees for Indonesia as a transit country that has not been ratified the 1957 Convention and its 1967 protocol. However, Indonesia as a sovereign country has the right to determine whether or not to obtain asylum in Indonesia, but Indonesia must pay attention to the basic rights inherent to every human being.

The 1951 Convention Relating to the Status of Refugee sets minimum standards of rights to be obtained for refugees, in which refugees receive the same standards of treatment that local citizens are interested in. Those rights include:

1. The right not to be repatriated to a country where the refugees have reason for fear of persecution (Article 33);

2. The right not to be expelled, except in very specific circumstances (Article 32);

3. Exclusion of penalties for illegal infiltration to States Parties to this Convention (Article 31);

4. The right to work (Article 17);

5. The right to own a house (Article 21);

6. The right to education (Article 22);

7. The right to general assistance (Article 23);

8. The right to freedom of religion (Article 4);

9. The right to legal services (Article 16);

10. Freedom of movement within the territory of the state (Article 26);

11. The right to obtain identity card (Article 27); 
If Indonesia becomes a party of the Refugee Convention, then Indonesia must implement the provisions stipulated in the Convention as mentioned above. However, Indonesia finds it difficult to ratify the Convention, due to those provisions are very heavy to be implemented. For example, Article 17 contains the right to work for refugees and Article 21, the right to own a house for a refugee.

It is common knowledge that Indonesia is a developing country, in which half of its population is living in poverty with limited job opportunities (Handayani, 2012). Moreover Article 21 contains provision to provide housing facilities for the refugees is very difficult to achieve, while many areas in Indonesia actually still need decent infrastructure from the central government. Therefore, if the government provides housing facilities for the refugees, it would be inappropriate policy for Indonesia's current condition.

As explained before, the Government of Indonesia has issued Presidential Decree on 31 December 2016 called Republic of Indonesia Presidential Regulation Number 125 Year 2016 on the Handling of Refugees From Abroad. Generally, this regulation fills a legal vacuum which has long been affected asylum seekers and refugees in Indonesia. It confirms Article 28G of the Indonesian Constitution, and Article 25-27 of Law No. 37 of 1999 on Foreign Relations.

Some scholars argued that this regulation should become the key regulation and reference for all Indonesian government officials in relation to the treatment of asylum seekers and refugees within Indonesian jurisdiction. Based on this presidential regulation, there is now an established coordination and a clear function by government in relation to the treatment of asylum seekers, no matter the mode of their arrival.

In the meantime, the implementation of this presidential regulation will increase understanding among government officials, and in turn increase the ability of officers in the field to implement it. Previously, asylum seekers and refugees were often viewed as illegal immigrants. The presence of this presidential regulation encourages the government to disseminate it widely and provide training to local government agencies across Indonesia, in order to ensure its effectiveness and compliances, especially in areas where asylum seekers and refugees are held in detention or live in the community, such as Aceh, Makassar, Medan, Tanjung Pinang, Kupang, and West Java.

In relation to those standards, since an enactment of the regulation, the Director of Law and Human Rights of the Foreign Affairs Ministry of the Indonesian Republic, Dicky Komarudin said, in principle, the presidential regulation provides a legal framework for all practices that have been implemented. Some of the things that are substantively gripped today are the clarity of funding that has always been a problem, especially for the regions that receive or accommodate the asylum seeker and the refugees. Coordination, with the presence of this presidential regulation, becomes increasingly clear, starting from the stage of discovery, shelter, security, and supervision of immigration. This presidential regulation also provides the possibility for the government to build a shelter facility for asylum seekers and refugees. Therefore, the nature of this presidential regulation seems futuristic for managing refugees in Indonesia (Media Indonesia, 2017). Tri Nuke Pudjiastuti, the researcher of Lembaga Ilmu Pengetahuan Indonesia (LIPI), also added that, generally the presence of the 7th chapter with 44 articles gives relief to the stakeholders and the government, both at the central and regional levels in the framework of coordinating the handling of refugees and asylum seekers. This presidential regulation provides a clearer framework in the matter of coordination, so no need to wait when there is an incident (Media Indonesia, 2017).

The issuance of this presidential refugee regulation is also highly appreciated by UNHCR representative for Indonesia, Thomas Vargas who claimed that this regulation is in line with the ideas embodied in the 1951 
Refugee Convention and its 1967 Protocol (Hasan, 2017). Thus, it indicates that Indonesia has committed in providing safe shelters for refugees without having to adopt such international convention and its protocol. Moreover, the next challenge for the government is to ensure that the regulation is well implemented. The implementation of the regulation should balance out of its three aspects. They are the effectiveness of handling and coordination in the field, respect for human rights, and the fulfillment of the supervisory aspects of foreigners and state security.

First, the effectiveness of handling and coordination in the field. Based on UNHCR 2016 data, there are currently an estimated 14,405 foreign refugees and asylum seekers residing in Indonesia. A total of 1,946 people living in immigration detention houses spread across 13 regions; 2,000 of people are handled by the community house, and the rest are allowed to independently take care of their needs by staying under immigration supervision. Ironically, there are refugees who have lived for five to ten years in Indonesia and they have not been handled properly. The handling of refugees, after the issuance of presidential refugee regulation, is regulated Article 2(1) where refugee management is handled under the cooperation of the central government and the United Nations through the high commissioner for Refugee Affairs in Indonesia and/or with other international organizations, while, the central government refers to the coordination between ministers as mentioned in Article 4(1). This is consistent with Article 27 of Law Number 37 Year 1999 concerning foreign relations which states that the President sets the policy regarding refugees from abroad with the consideration from his Ministers. Generally, this presidential refugee regulation contains many technical provisions regarding the handling of foreign refugees in Indonesia. Such as, technical provisions for refugees who are in an emergency situation and dead. The issuance of this presidential refugee regulation is considered the right move to overcome many problems of refugees in Indonesia. This regulation, if studied closely, has not yet regulated on many things, like prevention, repatriation, and fully responsible parties, which overstay in Indonesia since Indonesia is not a contracting state to the 1951 Refugee Convention.

Second, aspects of respect for human rights. Indonesia, although, has not ratified the 1951 Refugee Convention, its legislation is sufficient to justify that the Indonesia government both from the normative aspect and the practice of refugee handling has upheld the values of human rights. Particularly in the last five years, the government has made a real step, one of them in exploring a number of alternative solutions related to the placement of non-detention migrants. Non-detention accommodation in Indonesia is described in the Regulation of the Director General of Immigration, which facilitates the provision of accommodation beyond detention for refugees/asylum seekers.

Furthermore, Immigration Act and Standard Operational Procedure for Immigration Detention House specifically states that pregnant women, sick people, and children can be placed outside the Immigration Detention Center (RUDENIM). This is reaffirmed in Article 27(3) of Presidential Regulation No. 125 of 2016 under certain conditions refugees with special needs which may be placed outside the facilitated shelter. Refugees with special needs include:
(a) Sick;
(b) Pregnant;
(c) Persons with disabilities;
(d) Child;
(e) Elderly. 
According to the International Organization for Migration (2014), at the end of August 2014, about 2,599 migrants under IOM Indonesia care were placed in 42 accommodation facilities spread across six provinces in Indonesia. These facilities generally accommodate refugees and asylum seekers, including migrant groups with special needs such as women, children, the elderly, and persons with disabilities. The ratio between male and female migrants in accommodation is $10: 3$, while $67 \%$ of the total residents are adult migrants. Types of accommodation facilities for migrants range from low-cost housing complexes, guesthouses, to low-cost hotels. Each accommodation is designed as an integrated housing with facilities to support a decent standard of living. Each facility is located fairly close to public transport facilities, markets, and health care venues. This standard is reaffirmed in Article 26 Paragraph 5 of Presidential Refugee Regulation, where basic facilities as referred to in Paragraph 4, include:

(a) Clean water supply;

(b) Fulfillment of food, drink, and clothing needs;

(c) Health and hygiene services;

(d) Worship facilities.

Third, the fulfillment of the supervisory aspects of foreigners and state security. The presence of foreigners in a country in many cases threatens the stability of state security, in Indonesia for example dozens of Nigerian refugees using UNHCR pocket money or donor agencies for drug abuse. There are also young refugees who become gigolo in Batam; impregnate local girls even steal someone’s wife. In terms of national resilience, it is important to be aware whether any foreigner who declares himself to be a refugee is a foreign spy or member of an international terrorist network that intends to spread his ideology. Not to mention if the refugees carry epidemic diseases that can be endemic in Indonesia, while refugees also have the right to mobility and interact with local residents.

In the General Explanation Section of Immigration Act Number 6 of 2011, it stated that the service and supervision of foreigners is conducted on the principle of "selective policy". Article 71 of Law Number 6 Year 2011 on Immigration states that conducting the registration of foreigners in Indonesia is obliged to:

(a) Provide all necessary information about his/her identity and/or family, changes in civil status and citizenship, and change of address;

(b) Show the travel document or immigration document it possesses at the time required for the supervision;

(c) Enroll if in Indonesia more than 90 days.

The collection of data by means of foreign control is conducted for every foreign person who:

1. Enter or exit the territory of the Republic of Indonesia;

2. Be in the territory of the Republic of Indonesia;

3. Conduct, activities in the territory of the Republic of Indonesia.

In order to achieve the principle of selective policy, according to Warhan Wirasto Suhaidi (2016), it required the supervision of foreigners where its purpose is to protect the public and the sovereignty of the country from foreigners who do not bring good and positive benefits. Supervision of foreigners also includes security aspects. Article 32 Security of Refugees at shelters shall be carried out by appointed officials as referred to in Article 25 Letter A, in coordination with the Police of the Republic of Indonesia:

(a) Keeping IDPs in shelters;

(b) Creating a sense of security for the environment around the shelter; 
(c) Creating and socializing the rules that contain obligations and prohibitions for refugees.

Chapter V(5) About Immigration Control consists of Articles 33-39, which contain technical requirements from the time that they are found, in shelters and outside the shelter, to the destination country, return voluntarily, and deportation.

\section{Conclusion}

Historically, refugee management in Indonesia both in terms of rules and practices has been well implemented, although Indonesia is not a state party to the 1951 Convention Relating to the Status of Refugee Convention and its 1967 Protocol. The management is based on the principle of respecting the human dignity which is mandated in the ideology of the Indonesian nation, namely Pancasila, which is further elaborated in the 1945 Constitution, especially Articles 28A through 28J, Law Number 37 Year 1999 on International Relations, Law Number 39 Year 1999 on Human Rights, and other series of rules and regulations in Indonesia.

Indonesia's commitment in upholding human rights is increasingly shown by the issuance of the Presidential Decree of Indonesian Republic No. 215 of 2016. This regulation has become the legal framework for local governments, especially the areas that visited by refugees and asylum seekers. Implementation of the regulation should balance the three aspects of the effectiveness in handling and coordination in the field, respect for human rights, and the fulfillment of the supervisory aspects of foreigners and state security. Thus, to achieve these three aspects requires another supporting rule, such as regional rules.

\section{References}

Amiruddin. (2004). Pengantar Metode Penelitian Hukum. Jakarta: Raja Grafindo Press.

Charliene, A. (2017). Challenges and opportunities in responding to refugee and asylum seeker entering Indonesian territory in the context of implementing presidential regulation Number 125 Year 2016. Retrieved from http://etd.repository.ugm.ac.id/index.php?mod=penelitian_detail\&sub=PenelitianDetail\&act=view\&typ=html\&buku_id=114 482\&obyek_id=4

Cain, B. E. (1999). Election law as a field: A political scientist's perspective. Loyola of Los Angeles Law Review, 32, $1105-1120$.

Clarissa, F. (2014). Tinjauan Hukum Internasional atas Search and Rescue terhadap Pencari Suaka yang Berada dalam Keadaan Bahaya di Laut (Undergraduate Thesis Universitas Indonesia, Depok).

Human Rigts Watch. (2013). Barely surviving detention, abuse and neglect of migrant children in Indonesia.

Hamid At-Tamimi, A. (1993). Pancasila: The ideal law of the life of the Indonesian Nation. Paper presented at BP7 Center, Jakarta. Retrieved from http://digilib.uinsby.ac.id/6423/4/Bab\%202.pdf (accessed on 2 Feb. 2018)

Hamid At-Tamimi, A. (1991). Pancasila: Cita Hukum dalam Kehidupan Hukum Bangsa Indonesia: Pancasila sebagai Ideologi dalam Berbagai Bidang Kehidupan Bermasyarakat, Berbangsa dan Bernegara. Jakarta: BP7 Pusat.

Hamidi, J. (2009). Teori dan Politik Hukum Tata Negara. Yogyakarta: Total Media.

Handayani, I. P. (2012). Beyond statistics of poverty. Jakarta Post. Retrieved from http://www.thejakartapost.com/news/2012/02/13/beyond-statistics-poverty.html (accessed on December 1st, 2017)

Hasan, R. A. (25 Jul. 2017). UNHCR Puji Perpres Baru RI Untuk Pengungsi. Retrieved from http://www.liputan6.com/global/read/3034088/unhcr-puji-perpres-baru-ri-soal-penanganan-pengungsi

IOM. (September 2014). Tempat Penampungan Pengungsi Sekupang. Retrieved from http://indonesia.iom.int/sites/default/files/News-September-IND-zpo7_0.pdf

Indonesia_UPR $\quad$ Info. $\quad$ 30th, $\quad$ 2018). Retrieved from https://www.upr-info.org/sites/default/files/document/indonesia/session_27_-_may_2017/unhcr_upr27_idn_e.pdf

Krustiyati, A. (2012). Kebijakan Penanganan Pengungsi di Indonesia, Kajian Dari Konvensi Pengungsi tahun 1951. Surabaya: UBAYA.

Mahfud MD, M. (1998). Politik Hukum di Indonesia. Jakarta: LP3ES. 
Media Indonesia. (9 March 2017). Pendanaan dan Koordinasi Pengungsi kian Jelas. Retrieved from http://mediaindonesia.com/news/read/95732/pendanaan-dan-koordinasi-pengungsi-kian-jelas/2017-03-09 (accessed on 2 February 2018)

Muhammad, A. (2004). Hukum dan Penelitian Hukum. Bandung: PT, Citra Aditya Bakti.

Raharjo, S. (2000). Ilmu Hukum. Bandung: Citra Aditya Bakti.

Soedarto. (1983). Hukum Pidana dan Perkembangan Masyarakat dalam Kajian Hukum Pidana. Bandung: Sinar Baru.

Soekanto, S. (1981). Pengantar Penelitian Hukum. Jakarta: UI Press.

Santoso, T. (2005). Penulisan Proposal Penelitian Hukum Normatif (Delivered in Legal Research Course, Faculty of Law Universitas Indonesia, Depok).

Shahrullah, R. S., \& Syarif, E. (2015). Proposing an integrated-progressive model in handling troubled Indonesia overseas workers in the Transit Area (A socio-legal research in Tanjung Pinang City, Kepulauan Riau Province). Indonesia Law Review, 5(3), 305-323.

Suhaidi, W. W. (2016). Pelaksanaan pengawasan warga negara asing di wilayah kerja kantor imigrasi kelas ii belawan berdasarkan uu no. 6 tahun 2011 tentang keimigrasian. USU Law Journal, 4(1), 168-185.

UNHCR. (1 March, 2018). Figure at a glance. Retrieved from http://www.unhcr.org/figures-at-a-glance.html

UNHCR di Indonesia. (1 March, 2018). Retrieved from http://www.unhcr.org/id/unhcr-di-indonesia

Wahyono, P. (1986). Indonesia Negara Berdasatkan atas hokum. Ghalia Indonesia, Jakarta: Cet. II.

Wahyono, P. (1991). Menyelisik Proses Terbentuknya Perundang-Undangan. Forum Keadilan, No. 29, April 1991.

Wignyosoebrata, S. (1993). Metodologi Penelitian Hukum, Diktat (Kumpulan Tulisan). Surabaya: Program Pascasarjana UNAIR.

Zevenbergen, W. (2011). Political law. Jakarta: Sinar Grafika. 